DOI: $10.15193 /$ zntj/2019/119/291

\title{
JOANNA M. DZIADKOWIEC \\ KONSUMENCKA OCENA JAKOŚCI POTRAW OFEROWANYCH PRZEZ RESTAURACJE O CHARAKTERZE REGIONALNYM
}

\begin{abstract}
Streszczenie
Tradycje kulinarne należą do dziedzictwa kulturowego danego regionu lub kraju. Ich kultywowanie nie ogranicza się do gospodarstw domowych. Konsument, zwłaszcza turysta, oczekuje, że produkty i potrawy regionalne bądź tradycyjne będą domeną restauracji o charakterze regionalnym. Tego typu żywność jest popularyzowana podczas licznych targów, festynów czy festiwali smaków organizowanych w różnych regionach Polski, co dodatkowo zwiększa popyt na nią.

Celem pracy była konsumencka ocena jednego z aspektów jakości usług gastronomicznych, tj. jakości posiłków, na które składają się walory sensoryczne, jakość zdrowotna oraz dyspozycyjność. Przedmiotem badań były restauracje o charakterze regionalnym, w których powinna być oferowana żywność tradycyjna i regionalna. Z przeprowadzonych badań wynika, że respondenci mając do wyboru restauracje o charakterze regionalnym i nieregionalnym zdecydowanie częściej wybierają te pierwsze. Pojęcie żywności regionalnej i tradycyjnej traktują jednak intuicyjnie, z reguły nie przywiązują wagi do tego, czy oferowane produkty są certyfikowane. Jakość posiłków spożywanych w lokalach o charakterze regionalnym została oceniona średnio na poziomie 3,41 (w skali 5-stopniowej). Ocena ta nie odbiega znacząco od oceny pozostałych restauracji oferujących usługi na analizowanym obszarze. W przypadku restauracji regionalnych najwyżej zostały ocenione walory sensoryczne oferowanych posiłków $(3,81)$, nieznacznie niżej oceniono jakość w aspekcie dyspozycyjności $(3,44)$, najniżej natomiast - w aspekcie jakości zdrowotnej $(3,20)$.
\end{abstract}

Słowa kluczowe: usługi gastronomiczne, jakość żywności, jakość usług, produkty regionalne, satysfakcja klienta

\section{Wprowadzenie}

Tradycje kulinarne są jednym z wyróżników danego regionu i mają duży wpływ na zwiększenie jego atrakcyjności turystycznej. W wielu regionach do produkcji żywności wykorzystuje się podobne surowce, a specyfika kuchni regionalnej polega na ich wyjątkowej metodzie łączenia, stosowaniu innych technik kulinarnych, sposobie ser-

Dr hab. J. M. Dziadkowiec, prof. nadzw., Katedra Zarzadzania Jakościa, Wydz. Towaroznawstwa i Zarzadzania Produktem, Uniwersytet Ekonomiczny w Krakowie, ul. Rakowicka 27, 31-510 Kraków. Kontakt:dziadkoj@uek.krakow.pl 
wowania lub nazewnictwie. Regionalne potrawy różnią się więc od siebie i często - ze względu na szczególny sposób wytwarzania i niepowtarzalne walory sensoryczne stają się wizytówkami regionów.

Polską kuchnię dzieli się na dziesięć regionów kulinarnych: Beskidy, Pomorze i Kaszuby, Wielkopolskę, Podhale, Śląsk, Galicję, Warmię i Mazury, Mazowsze, Kresy [19]. Zarówno w świadomości konsumentów, jak i w literaturze funkcjonują też inne podziały, które wskazują na specyfikę kulinarną subregionów lub grup etnicznych zamieszkujących ten region. W kontekście tradycyjnej kuchni można więc mówić także o kuchni góralskiej, wielkopolskiej, śląskiej, kaszubskiej, mazurskiej, małopolskiej i galicyjskiej [1], podhalańskiej, kurpiowskiej i podlaskiej [27], tradycjach kulinarnych poszczególnych województw [24], a nawet konkretnych miast [5].

Jednym z regionów o bogatej i zróżnicowanej tradycji kulinarnej jest Małopolska. Stolicą regionu jest Kraków, który na przestrzeni wieków, podobnie jak cała Małopolska, doświadczył wielu zmian politycznych i administracyjnych. W okresie zaborów Małopolska została podzielona. Część została w Królestwie Polskim, a część południowa znalazła się w zaborze austriackim pod nazwą Galicja. Obszar ten, ze względu na mieszkającą tam ludność ukraińską i żydowską, a także silne wpływy austriackie i węgierskie, wykreował bardzo charakterystyczną kuchnię galicyjską [32]. Galicyjskie tradycje kulinarne nie są jednolite, można zauważyć geograficzny podział kuchni galicyjskiej m.in. na kuchnię podhalańską, huculską, krakowską (małopolską, zachodniogalicyjską) i lwowską (wschodniogalicyjską) [26]. Pod względem turystycznym szczególne znaczenie ma kuchnia podhalańska, zwana także góralską, która w połączeniu z autentycznym i żywym folklorem góralskim, kultywowanym na co dzień w wielu miejscowych rodzinach, stała się wizytówką regionu.

Dziedzictwo kulinarne Małopolski można rozpatrywać jako dwie tradycje kulinarne, które składają się na obraz tego, co można współcześnie uznać za produkty i potrawy regionalne. Jest to tradycyjna kuchnia chłopska, która wywarła największy wpływ na współczesne nawyki żywieniowe mieszkańców regionu, oraz kuchnia dworska. Na małopolską kuchnię wpływ miały także inne kultury, których przedstawiciele zamieszkiwali ten region, charakterystyczne są zwłaszcza wpływy kultury żydowskiej czy też wschodniej [31].

Typowym przykładem kuchni wiejskiej jest kuchnia podhalańska, która kształtowała się w trudnych warunkach klimatycznych Podhala - spożywano to, co w ubogim góralskim gospodarstwie wyprodukowało i nie przetworzono w celu odsprzedania. Podstawą były gotowane ziemniaki, a także dania mączne, jako omasty używano topionej słoniny, skwarków, czasami oleju lnianego. Mleko słodkie i kwaśne pojawiały się na stołach jedynie odświętnie, ponieważ produkty takie jak ser biały, masło, oscypki, jaja starano się sprzedawać, spożywano natomiast głównie serwatkę, maślankę oraz żętycę. Charakterystyczne były również dania z kiszonej kapusty [14]. 
Duża popularność, a nawet swoista moda na spożywanie produktów regionalnych spowodowała, że produkty i potrawy regionalne i tradycyjne oferowane są praktycznie wszędzie, zwłaszcza w pobliżu atrakcji turystycznych. Są one na ogół kojarzone z wysoką jakością, czasem nawet traktowane jako dobro luksusowe [21]. W badaniach potwierdzono także, że według konsumentów żywność tradycyjna i regionalna jest „zdrowa”, ma szczególne walory smakowe i zapach, jest wytwarzana z naturalnych składników, bez dodawania konserwantów i innych dodatków [2, 23, 36]. Konsumenci wysoko cenią również sposób wytwarzania, na który składają się tradycyjne receptury powiązane ze specyficznymi metodami produkcji oraz przygotowywanie żywności domowymi sposobami, z zachowaniem naturalnych, długotrwałych i pracochłonnych procesów technologicznych, ale gwarantujących niezmienną od pokoleń wysoką jakość [13].

Powszechna obecność żywności tradycyjnej i regionalnej na rynku powoduje, że potrzebna jest weryfikacja autentyczności proponowanych produktów i potraw - konsument może ocenić walory organoleptyczne, jednak nie jest w stanie zweryfikować składu produktu czy też metody wytwarzania.

Rejestracja i ochrona nazw produktów regionalnych i tradycyjnych istnieją w UE od 1992 roku. Ich celem jest promocja i ochrona żywności wysokiej jakości, której produkcja związana jest z określoną tradycją bądź konkretnym regionem geograficznym. Rejestracja nazw produktów regionalnych i tradycyjnych na szczeblu unijnym umożliwia uzyskanie prawa do stosowania oznaczeń, takich jak: Chroniona Nazwa Pochodzenia, Chronione Oznaczenie Geograficzne oraz Gwarantowana Tradycyjna Specjalność. Dzięki temu możliwa staje się certyfikowana ochrona wyrobów oraz oficjalne potwierdzenie wysokiej jakości i gwarancji pochodzenia produktów opatrzonych symbolem jednego z trzech oznaczeń [11]. W aktualnie obowiązującym Rozporządzeniu Rady określone zostało, że „tradycyjny” oznacza udokumentowany jako będący w użyciu na rynku krajowym przez okres umożliwiający przekaz z pokolenia na pokolenie, przy czym okres ten ma wynosić co najmniej 30 lat. Produkt powinien mieć również „specyficzny charakter”, co oznacza charakterystyczne właściwości procesu produkcji, które wyraźnie wyróżniają dany produkt spośród innych podobnych produktów należących do tej samej kategorii [25].

Specyfika regionalnej żywności tradycyjnej powoduje, że w jej przypadku konkurencyjność można rozpatrywać zarówno $\mathrm{z}$ uwagi na przedsiębiorstwa wytwarzające produkty tradycyjne, jak i regiony, z których kulturą kulinarną jest związana, zwłaszcza gdy są to regiony turystyczne [29]. Konsumenci mogą zetknąć się z produktami regionalnymi najczęściej w kilku formach. Mogą nabywać produkty, które zostały zarejestrowane jako regionalne, dokonywać zakupu bezpośrednio u lokalnych wytwórców i na różnego rodzaju targach, festynach czy festiwalach smaków. Mogą także odwiedzać miejsca, gdzie można kupić i spróbować produktów kuchni lokalnej, takich 
jak sklepy z produktami i żywnością regionalną, obiekty związane z produkcją żywności (np. winnice, browary, piekarnie) oraz karczmy i zajazdy [30]. Polacy chętnie korzystają z lokali gastronomicznych nie tylko w trakcie pobytów turystycznych, ale również w trakcie podróży do miejsca docelowego [7, 8]. Coraz częściej wykazują także gotowość do wydania większej kwoty pieniędzy oraz nadłożenia drogi w celu spożycia nowych, smacznych potraw podawanych w wyjątkowym miejscu [33].

Jedną z tras, gdzie turyści chętnie korzystają z usług gastronomicznych lokali o charakterze regionalnym, jest tzw. Zakopianka, czyli droga łącząca Kraków i Zakopane. Liczba obiektów usytuowanych wzdłuż tej drogi oraz ich różnorodność sprawia, że jest to miejsce wyjątkowe pod względem kulinarnym. Wzdłuż drogi usytuowanych jest 46 lokali gastronomicznych, w tym 27 restauracji. Zdecydowana większość restauracji (oraz część lokali z pozostałych kategorii) ma charakter regionalny, który jest podkreślany przez nawiązanie do tradycyjnego budownictwa miejscowego, zarówno w przypadku zewnętrznego wyglądu budynku, jak i wyposażenia i aranżacji wnętrz. W większości z nich można spożyć posiłki reklamowane jako tradycyjne i/lub regionalne, często charakter restauracji podkreślany jest nazwą (karczma, oberża), strojami kelnerów oraz muzyką, czasem również graną na żywo [7]. W karczmach i oberżach serwowana jest przede wszystkim kuchnia podhalańska (góralska) oraz zdecydowanie rzadziej kuchnia nawiązująca do tradycji galicyjskich. Z przeprowadzonych badań wynika, że jakość usług oferowanych przez lokale gastronomiczne postrzegana przez konsumentów jest dość wysoka, jednak występują znaczące różnice pomiędzy poszczególnymi placówkami [7]. Analiza rdzenia usługi, tj. jakości serwowanych posiłków, wskazuje na to, że ogólna ocena konsumencka jakości potraw jest przeciętna, niezależnie od kategorii lokalu gastronomicznego [6].

Celem niniejszej pracy była konsumencka oceny jakości potraw oferowanych przez restauracje o charakterze regionalnym. Założono, że w przypadku tych lokali jakość posiłków będzie oceniana wyżej niż w przypadku placówek o standardowej ofercie, która nie nawiązuje do kuchni regionalnej.

\section{Material i metody badań}

Badania przeprowadzono wśród konsumentów, którzy w trakcie podróży na Podhale skorzystali z usług gastronomicznych oferowanych przez lokale gastronomiczne usytuowane wzdłuż tzw. Zakopianki. Badania zostały przeprowadzone w pobliżu 6 atrakcji turystycznych Podhala. Grupą docelową były osoby, które miały 18 lat lub więcej, skorzystały z usług gastronomicznych podczas podróży ww. drogą i dotarły do miejsca docelowego nie później niż 1 dobę przed badaniem. Badania przeprowadzano metodą indywidualnych bezpośrednich wywiadów kwestionariuszowych (PAPI). Wzięło w nich udział 1455 respondentów, w tym 844 osoby skorzystały z usług restauracji, pozostałe natomiast $-\mathrm{z}$ usług gastronomicznych świadczonych przez stacje pa- 
liw, lokale fast food oraz bary. W badaniach najliczniej były reprezentowane osoby z przedziałów wiekowych 35 - 44 lata $(27,5 \%)$ oraz $25-34$ lata $(26,0 \%)$. Osoby z najstarszych grup wiekowych stanowiły odpowiednio: 18,1\% (45 - 54 lata) oraz $12,0 \%$ (powyżej 54 lat), natomiast najmłodsza grupa wiekowa (18 - 24 lat) stanowiła 16,4 \% badanej populacji. Wśród respondentów mężczyźni stanowili 50,4\%, natomiast kobiety - 49,6\%. Większość respondentów (40,5\%) miała wykształcenie wyższe, 34,2 \% - wykształcenie średnie, natomiast 25,3\% - wykształcenie zawodowe lub podstawowe.

Narzędziem badawczym był kwestionariusz pochodzący z czteroczynnikowego modelu jakości usług gastronomicznych przeznaczonych dla zmotoryzowanych podróżnych. Zgodnie z modelem czynnikami determinującymi wymagania wobec lokali z kategorii roadside dining facilities są: czystość i higiena, sprawność obsługi i bezpieczeństwo, jakość lokalu i otoczenia oraz relacja cena - ilość. Do analizy w niniejszym opracowaniu zostały wykorzystane kryteria odnoszące się do różnych aspektów związanych z jakością posiłków (w sumie 11 zmiennych z 30), które zostały przyporządkowane do trzech czynników determinujących jakość żywności. Te czynniki to: walory sensoryczne, dyspozycyjność oraz jakość zdrowotna żywności. Zmienne wchodzące w skład poszczególnych czynników przedstawiono na rys. 1. Respondenci oceniali stopień swojego zadowolenia z poszczególnych aspektów składających się na usługę gastronomiczną w skali 5-stopniowej, gdzie 1 oznacza całkowity brak zadowolenia (w ogóle niezadowolony), a 5 - pełne zadowolenie (całkowicie zadowolony). Respondentom zadano dwa pytania otwarte, których celem było sprawdzenie, jak rozumieją oni pojęcie produktu lub potrawy regionalnej/tradycyjnej: skąd wiedzą, że dany produkt/potrawa jest regionalna/tradycyjna i w jaki sposób rozróżniają takie dania i produkty od pozostałych potraw.

W celu dokonania analizy porównawczej jakości usług serwowanych przez restauracje regionalne zastosowano wykres rozproszenia, tworząc mapę jakości usług świadczonych przez nadane lokale; w tym celu wykorzystano średnią z próby. Porównania usług świadczonych przez restauracje o charakterze regionalny i pozostałe analizowane lokale gastronomiczne dokonano z wykorzystaniem testów t oraz F dla zmiennych niezależnych.

\section{Wyniki i dyskusja}

Respondenci w trakcie badania zadeklarowali, że korzystali ze wszystkich rodzajów usług gastronomicznych dostępnych wzdłuż pokonywanej trasy, tj. z restauracji, lokali fast food, usług małej gastronomii oferowanych przez stacje paliw oraz barów. Największa liczba respondentów (844 osoby, 58 \%) odwiedziła restauracje. Prawie $73 \%$ z nich spożyło posiłek w karczmach, zajazdach i restauracjach, oberżach i innych lokalach o charakterze regionalnym, takich jak: Bida (14,0\%), Biesiada $(11,7 \%)$, 
Siwy Dym (9,8 \%), Karczma Zadyma (9,3 \%), Chłopskie Jadło (8,8 \%), Krakowiacy i Górale (8,5 \%), Wilczy Głód (7,2 \%), Karczma u Borzanka (6,8 \%), Karczma u Stacha (6,5 \%), Polaniorka (6,2 \%), Nowina (6,0 \%) i Karczma Rąbanica (5,4 \%).

Jako powód wybrania konkretnej restauracji 79,6 \% badanych wskazało czynniki związane z regionalnym charakterem odwiedzanych lokali, takimi jak: zachęcający wygląd lokalu nawiązujący do tradycji regionalnych (głównie góralskich. Respondenci raczej nie byli zainteresowani poznawaniem tradycji galicyjskich), możliwość spotkania $\mathrm{z}$ kulturą regionu jeszcze przed dotarciem do docelowego miejsca wypoczynku oraz chęć spróbowania „czegoś regionalnego”. Z analizy wyników można wywnioskować, że Polacy, podobnie jak konsumenci z innych krajów $[3,9,18]$, postrzegają żywność tradycyjną jako wzmocnienie doświadczenia turystycznego, spotkanie z lokalną kulturą oraz spersonalizowany dostęp do prawdziwych tradycji etnicznych. Ważnym czynnikiem wyboru było także przekonanie, że posiłki serwowane w tego typu lokalach będą obfite i smaczniejsze niż w pozostałych lokalach oraz, że posiłki będą miały charakter „domowy” i tradycyjny. Potwierdza to opinie o kuchni regionalnej, sformułowane na podstawie wyników wcześniejszych badań, według których potrawy regionalne są postrzegane jako smaczne, zdrowe oraz pożywne [4, 20]. Pozostali badani najczęściej wybierali lokal, ponieważ znali go z poprzednich podróży lub zatrzymali się spontanicznie, bo spodobała im się dana restauracja. Uzyskane odpowiedzi potwierdzają szczególną rolę otoczenia zewnętrznego lokali o charakterze lokalnym, które często stanowi główny czynnik decydujący nie tylko o wyborze restauracji, ale także determinujący oczekiwania w odniesieniu do serwowanych posiłków $[8,10,12$, $28,34]$. Niewielki odsetek badanych $(3,6 \%)$ nie potrafił podać przyczyny skorzystania $\mathrm{z}$ usług danego lokalu.

Zdecydowana większość respondentów $(81,2 \%)$ zadeklarowała, że w odwiedzanych lokalach spożyła posiłek lub potrawę regionalną lub tradycyjną. Najczęściej wymienianymi potrawami były: smalec domowy oraz oscypek podawany w różnych formach jako przystawka. Spożywany posiłek zwykle składał się z zupy i drugiego dania. Za typowe regionalne zupy uznano: kwaśnicę, żurek z jajkiem i kiełbasą, barszcz czerwony (z krokietem lub uszkami), rosół oraz zupę gulaszową, często występującą pod nazwą „kociołek góralski”. Na drugie danie spożywano głównie tzw. dania barowe oraz pełne zestawy obiadowe - najczęściej mięsne, ale zdarzały się również dania z ryb. Wśród regionalnych dań barowych najczęściej wymieniano takie potrawy jak: pierogi (najczęściej „ruskie” lub ,wiejskie”), placki ziemniaczane z gulaszem (często występujące pod nazwą placek zbójnicki lub góralski), bigos i golonkę. Wśród dań mięsnych respondenci najczęściej wybierali kotlet schabowy, żeberka wieprzowe, karczek pieczony, szaszłyki (głównie wieprzowe i drobiowe), gulasz (wieprzowy i rzadziej wołowy) oraz dania z grilla - wszystkie te potrawy zostały wymieniane jako po- 
trawy tradycyjne, regionalne lub przygotowane z produktów regionalnych. Za regionalne danie rybne uznany został pstrąg - smażony lub z grilla.

$\mathrm{Z}$ analizy odpowiedzi na pytania otwarte wynika, że respondenci za regionalne uznają te produkty, które od dłuższego czasu są wytwarzane w danym regionie, wiążą się z tradycją danego regionu, są wytwarzane według przepisów, które stosowały poprzednie pokolenia, są wytwarzane $\mathrm{z}$ lokalnych produktów, $\mathrm{w}$ danym regionie istnieje długoletni zwyczaj ich wytwarzania, są wytwarzane jednostkowo, według domowych przepisów. Niewielki odsetek badanych odpowiedział, że produkty tradycyjne mogą być certyfikowane i od tego zależy, czy dany produkt można uznać za regionalny czy też nie.

Zauważyć można, że potoczne rozumienie pojęcia produktów regionalnych i tradycyjnych przez uczestników badania jest zbieżne $\mathrm{z}$ koncepcją zawartą $\mathrm{w}$ obowiązującym Rozporządzeniu Rady WE nr 1151/2012 z dnia 21.11.2012 r. [16]. Podobnie definiowane są także produkty lokalne, których cechą wyróżniającą jest to, że są produkowane $\mathrm{w}$ danym regionie, $\mathrm{z}$ lokalnych produktów, ale przede wszystkim mają tzw. tożsamość regionalną [22] oraz tzw. żywność etniczna, która charakteryzuje się tym, że wywodzi się z dziedzictwa i kultury grupy etnicznej i jest akceptowana kulturowo i społecznie przez konsumentów spoza tej grupy [17]. Z drugiej strony można zauważyć, że przy ocenie czy dany produkt można uznać za regionalny, czy też tradycyjny, respondenci również kierują się potocznym rozumieniem tego pojęcia. Niewielkie znaczenie ma dla nich informacja, czy na dany produkt uzyskano certyfikat gwarantujący jego autentyczność. Potwierdza to preferencje konsumentów zidentyfikowane w wyniku wcześniejszych badań, według których z jednej strony certyfikat nie stanowi szczególnie istotnego czynnika wyboru [20,35], z drugiej strony jednak tylko nieliczni konsumenci twierdzą, że certyfikat produktu tradycyjnego nie ma dla nich żadnego znaczenia [15].

Obecnie w województwie małopolskim na listę produktów tradycyjnych zostało wpisanych 213 produktów (stan na 25.06.2018.), w tym 38 - to gotowe potrawy i dania [18], które mogłyby się znaleźć w ofercie lokali gastronomicznych o charakterze regionalnym. Respondenci nie pytali jednak o te dania, a do oceny czy dana potrawa ma charakter tradycyjny, wystarczało im z reguły stwierdzenie, że potrawa jest serwowana $\mathrm{w}$ karczmie zlokalizowanej $\mathrm{w}$ danym regionie i ma regionalną nazwę. Za takie nazwy uznano te pisane gwarą lub zawierającą przymiotniki, takie jak: góralski, bacowski, gazdowski, zbójnicki, juhaski, podhalański, domowy, swojski lub wiejski. Wszystko to sprawia, że raczej nie można mówić, że respondenci uczestniczyli w doświadczeniu gastronomicznym o charakterze regionalnym, a wybierane przez nich posiłki, produkty, czy potrawy rzadko były oryginalne, tradycyjne i przygotowywane według zweryfikowanych, certyfikowanych receptur. 
Średnia ogólna ocena jakości potraw spożywanych w odwiedzanych restauracjach i karczmach o charakterze regionalnym wyniosła 3,41 (w skali 1 - 5) - rys. 1 .

Jakość potraw ogółem

1. Dyspozycyjność

1.1. Porcje odpowiedniej wielkości

1.2. Szeroki wybór potraw

2. Walory sensoryczne

2.1. Odpowiednia temperatura potraw

2.2. Atrakcyjny wygląd potraw

2.3. Smaczne potrawy

3. Jakość zdrowotna

3.1. Potrawy higienicznie przygotowywane

3.2. Potrawy ze składników wysokiej jakości

3.3. Potrawy i personel budzą zaufanie

3.4. Pewność, że potrawy nie zaszkodzą.

3.5. "Zdrowe" potrawy

3.6. Świeże potrawy

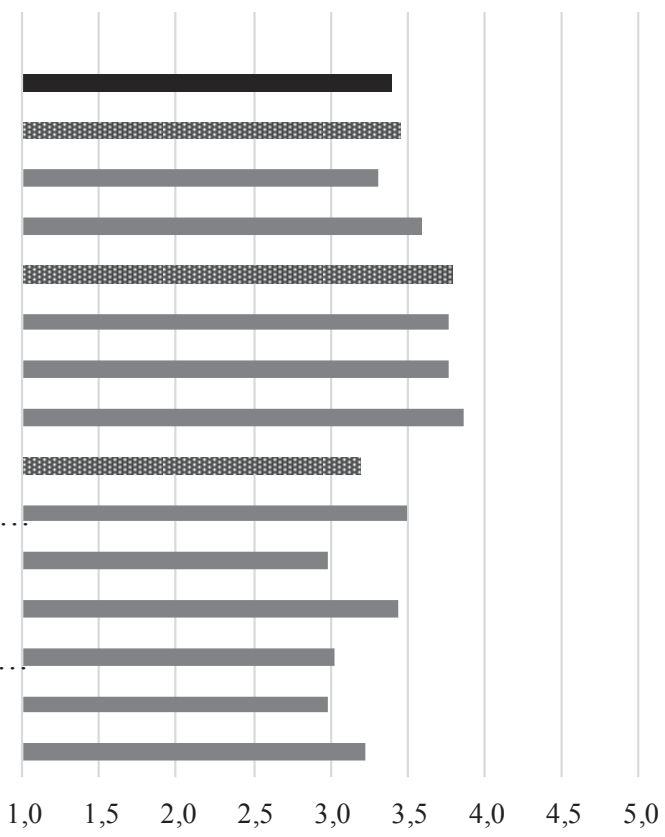

Objaśnienia / Explanatory notes:

Jakość potraw ogółem / Total quality of meals; 1. Dyspozycyjność / Availability; 1.1. Porcje odpowiedniej wielkości / Appropriate size of portions; 1.2. Szeroki wybór potraw / Wide range of dishes; 2. Walory sensoryczne / Sensory values; 2.1. Odpowiednia temperatura potraw / Adequate temperature of dishes; 2.2. Atrakcyjny wygląd potraw / Attractive look of dishes; 2.3. Smaczne potrawy / Tasty dishes; 3. Jakość zdrowotna / Health quality; 3.1. Potrawy higienicznie przygotowywane i podawane / Dishes hygienically prepared and served; 3.2. Potrawy ze składników wysokiej jakości / Dishes prepared with high quality ingredients; 3.3. Potrawy i personel budzą zaufanie / Dishes and staff inspire confidence; 3.4. Pewność, że potrawy nie zaszkodzą klientom / Assurance that the dishes will not cause health problems for customers; 3.5. “Zdrowe” potrawy / „Healthy” dishes; 3.6. Świeże potrawy / Fresh dishes.

Rys. 1. Czynniki determinujące jakość potraw serwowanych przez lokale gastronomiczne o charakterze regionalnym

Fig. 1. Determinants affecting quality of dishes served by regional restaurants

Źródło / Source: opracowanie własne / the author's own study

Najwyżej zostały ocenione walory sensoryczne serwowanych potraw, na które składały się: smak potraw, ich wygląd oraz temperatura podania - średnia ocena 3,81 oznacza, że respondenci byli „raczej zadowoleni” ze swoich doznań kulinarnych w tym zakresie. Nieco niżej $(3,44)$ oceniono została jakość w aspekcie dyspozycyjności, najniżej natomiast $(3,20)$ - aspekty związane $\mathrm{z}$ jakością zdrowotną serwowanych posiłków. W tym ostatnim aspekcie najwyższą aprobatę (na poziomie 3,46 ) respondenci wyrazili wobec stwierdzeń, że potrawy są higienicznie przygotowywane i serwowane 
oraz, że zarówno jedzenie, jak i personel budzą zaufanie. Największe wątpliwości (ocena ok. 3) respondenci mieli natomiast w stosunku do jakości produktów, z których przygotowywane były potrawy oraz wyrażali obawy, czy oferowane potrawy są „zdrowe” i im nie zaszkodzą (rys. 1).

Jakość posiłków serwowanych przez badane lokale była różna i wahała się w zakresie $2,89 \div 3,81$. Na rys. 2 . przedstawiono porównanie poszczególnych lokali z uwzględnieniem trzech czynników determinujących jakość żywności, tj. walorów sensorycznych, dyspozycyjności oraz jakości zdrowotnej.

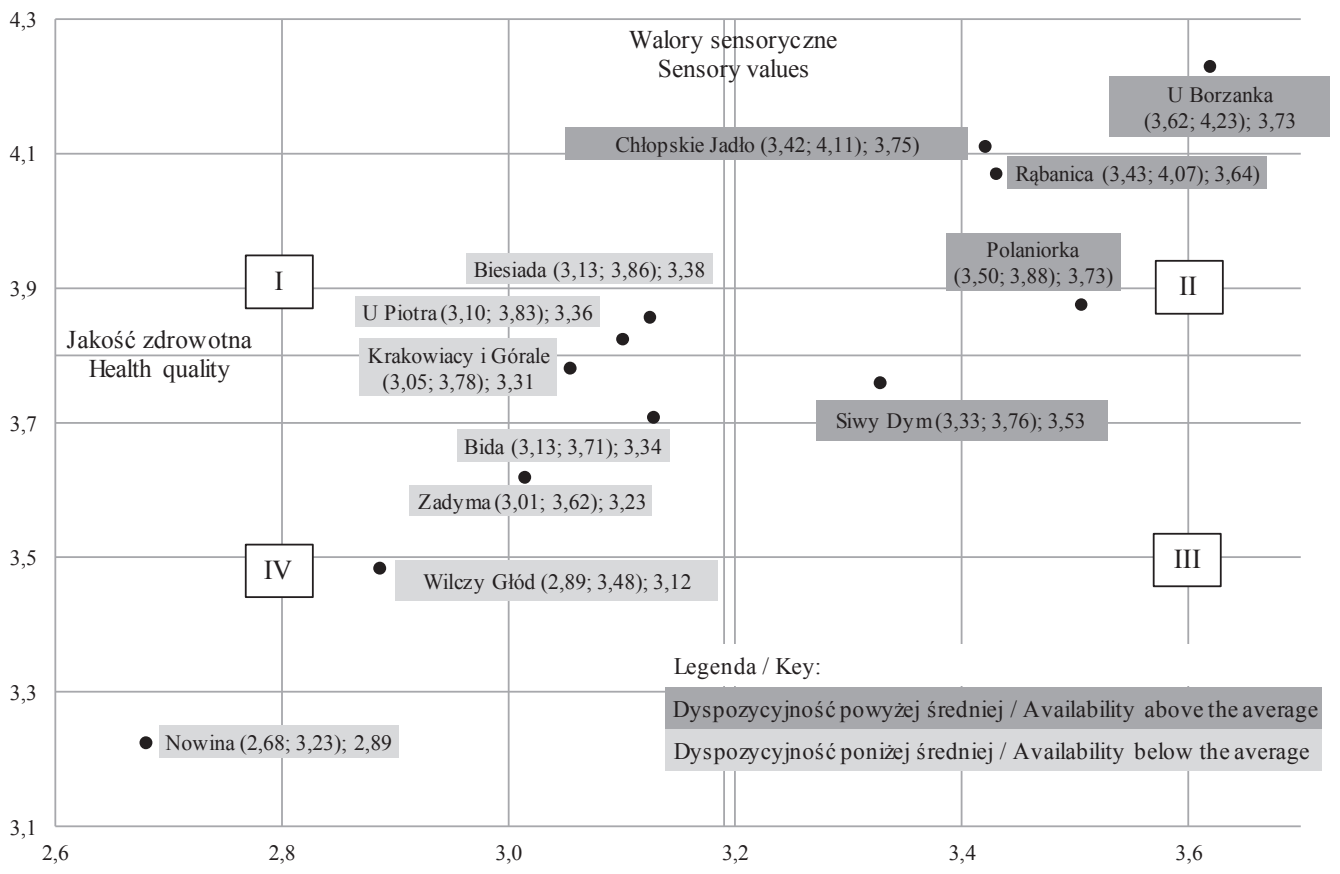

Rys. 2. Porównanie ocenianych lokali regionalnych ze względu na jakość serwowanych potraw

Fig. 2. Comparison of regional restaurants as regards the quality of dishes served Źródło / Source: opracowanie własne / the author's own study

Na rysunku, na osi pionowej przedstawiono konsumencką ocenę jakości zdrowotnej posiłków serwowanych w badanych restauracjach, natomiast na poziomejwalory sensoryczne, trzeci składnik jakości, tj. dyspozycyjność zaznaczono na wykresie dwoma odcieniami szarej barwy. W kwadracie II znalazły się restauracje oceniane najwyżej, czyli Karczma u Borzanka, Chłopskie Jadło, Rąbanica i Polaniorka - zostały one ocenione wyżej od pozostałych lokali w zakresie wszystkich trzech czynników determinujących jakość. W kwadracie I i II znalazły się restauracje, które mogą konkurować z pozostałymi w zakresie przynajmniej jednego czynnika determinującego ja- 
kość. W przypadku karczm: U Piotra i Biesiada (kwadrat I) powyżej średniej ocenione zostały walory sensoryczne, natomiast oferta restauracji Siwy Dym (kwadrat III) była konkurencyjna w zakresie jakości zdrowotnej oraz dyspozycyjności. Restauracje, które znalazły się w kwadracie IV oceniono niżej od średniej w zakresie wszystkich trzech ocenianych składników (rys. 2).

W celu sprawdzenia czy jakość posiłków serwowanych przez restauracje o charakterze regionalnym jest ich czynnikiem wyróżniającym, uzyskane wyniki porównano $\mathrm{z}$ ocenami, jakie przypisano pozostałym restauracjom przez osoby uczestniczące w badaniach (rys. 3 ).

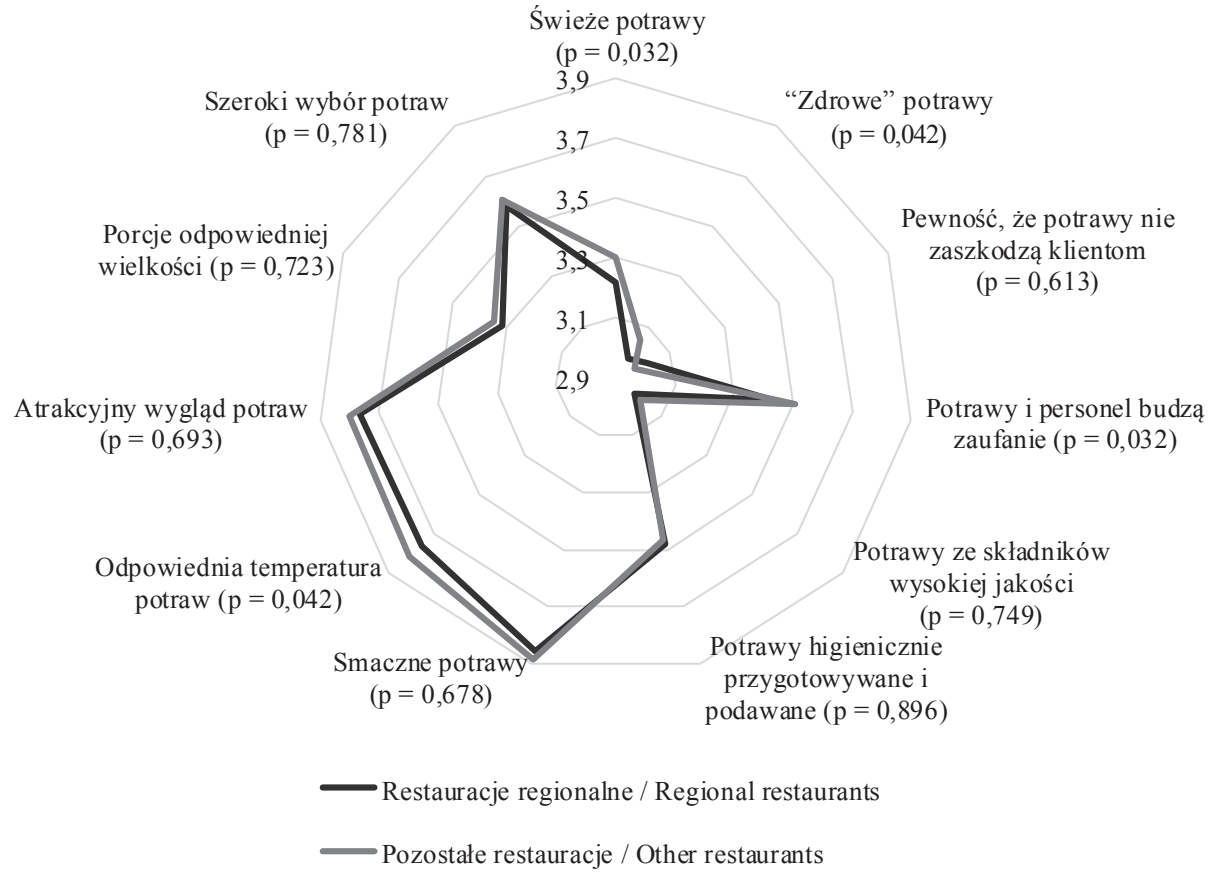

Objaśnienia jak pod rys. 1. / Explanatory notes as in Fig. 1.

Rys. 3. Porównanie jakości posiłków serwowanych przez restauracje o charakterze regionalnym i pozostałe restauracje

Fig. 3. Comparison of the quality of dishes served by regional and non-regional restaurants

Źródło / Source: opracowanie własne / the author's own study

Z przeprowadzonej analizy wynika, że oceny, jakie przyznano lokalom o charakterze regionalnym i pozostałym restauracjom były do siebie zbliżone - średnia ocena pierwszej grupy lokali wyniosła 3,41, natomiast drugiej - 3,43. Wykazano, że tylko 
w przypadku 4 spośród 11 analizowanych determinant jakości wystąpiły różnice statystycznie istotne $(p<0,05)$ między wartościami średnimi, przy czym wszystkie na korzyść restauracji nieregionalnych. W przypadku tych restauracji konsumenci częściej uznawali, że posiłki są świeże, ,zdrowe” i podawane w odpowiedniej temperaturze, mieli również większe zaufanie do personelu (rys. 3). Na korzyść restauracji o charakterze regionalnym przemawiała natomiast większa stabilność w zakresie jakości. Testem $\mathrm{F}$ wykazano, że w przypadku 7 pośród 11 analizowanych determinant odchylenie standardowe ma niższą wartość w przypadku tych lokali, przy czym w przypadku trzech na poziomie statystycznie istotnym $(\mathrm{p}<0,05)$.

Wśród tych determinant były dwie istotnie różnicujące badane grupy lokali pod względem średniej oceny, tj. temperatura posiłków oraz zaufanie do personelu. W praktyce oznacza to, że wprawdzie lokale nieregionalne były oceniane wyżej w tym zakresie, ale znacznie częściej konsumenci spotykali się tam z usługą odbiegającą od ustalonego standardu, zarówno w sensie pozytywnym, jak i negatywnym. Trzecią determinantą w tej grupie był smak potraw, który można uznać za jedną z mocniejszych stron lokali o charakterze regionalnym. Średnia ocena jakości była w tym przypadku tylko nieznacznie wyższa niż u konkurencji $(3,86$ w porównaniu z 3,83), jednak w przypadku zróżnicowania ocen stwierdzono zdecydowanie większe odchylenia w przypadku restauracji nieregionalnych (na poziomie istotności $\mathrm{p}=0,01$ ). Szczegółowe wyniki testu t oraz testu F przedstawiono w tab. 1.

Przyczyny takiej sytuacji nie były przedmiotem badania, można jednak przypuszczać, że taka ocena jakości wynika z tego, że zarówno klienci, jak i właściciele restauracji są zainteresowani raczej powierzchownym kontaktem z autentyczną kulturą kulinarną regionu. Konsumenci kwalifikują lokal jako regionalny przede wszystkim na podstawie oceny wyglądu zewnętrznego budynku, wyposażenia i aranżacji sali jadalnej, a także wyglądu i zachowania obsługi, dlatego właśnie te elementy są przedmiotem szczególnej troski restauratorów. Jak wynika z przeprowadzonych badań, klienci $\mathrm{z}$ reguły nie są zainteresowani autentycznością produktów potwierdzoną certyfikatem. Za potrawy regionalne uznawane są takie, które są serwowane w karczmie zlokalizowanej w danym regionie i mają regionalną nazwę. Tak rozumiana „regionalność” sprawia, że praktycznie wszystkie restauracje zlokalizowane na danym terenie serwują posiłki o charakterze regionalnym, podstawowa różnica dotyczy natomiast otoczenia zewnętrznego i wewnętrznego usługi gastronomicznej. 


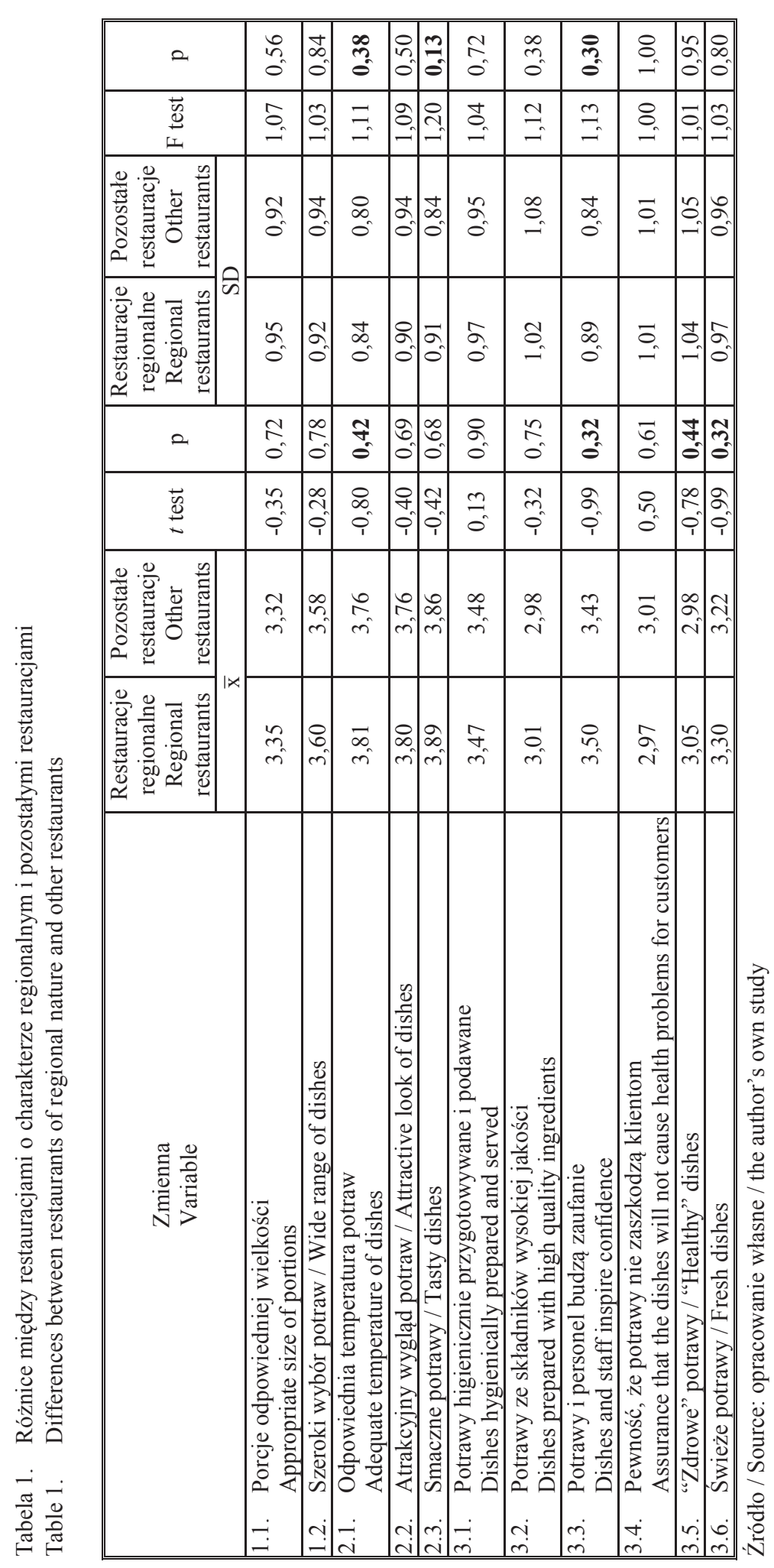




\section{Wnioski}

1. Jeśli klienci mają wybór, zdecydowanie preferują spożywanie posiłków w lokalach o charakterze regionalnym. W analizowanym przypadku aż 79,6 \% respondentów wybrało taką opcję, pomimo że na badanym obszarze dostępne są także restauracje o standardowej ofercie.

2. Osoby spożywające posiłki w badanych lokalach traktują pojęcie żywności regionalnej i tradycyjnej intuicyjnie, kojarzą te pojęcia z produktami wytworzonymi na danym terenie, $z$ lokalnych produktów, według miejscowych, tradycyjnych receptur. Natomiast $\mathrm{z}$ reguły nie przywiązują wagi do tego, czy dany produkt ma certyfikat gwarantujący jego autentyczność.

3. W przypadku restauracji regionalnych najwyżej zostały ocenione walory sensoryczne oferowanych posiłków $(3,81)$, nieznacznie niżej oceniono jakość w aspekcie dyspozycyjności $(3,44)$, najniżej natomiast - w aspekcie jakości zdrowotnej $(3,20)$.

4. Restauracje regionalne różniły się między sobą ze względu na poziom jakości oferowanych potraw, najniżej oceniono lokal na poziomie 2,89 , najwyżej natomiast na poziomie 3,81. Zgodnie z metodologią IPA tylko 4 restauracje oferują posiłki o satysfakcjonującej jakości, natomiast aż 5 - o jakości poniżej przeciętnej.

5. Jakość posiłków oferowanych przez restauracje o charakterze regionalnym oraz pozostałe restauracje była zbliżona i wyniosła odpowiednio: 3,41 i 3,43 (w skali 5-stopniowej).

6. Stwierdzono statystycznie istotne różnice między wymienionymi kategoriami lokali w przypadku 4 zmiennych. Respondenci wyżej ocenili potrawy serwowane w restauracjach regionalnych ze względu na ich świeżość, walory zdrowotne i temperaturę podania, ponadto zarówno personel, jak i serwowane posiłki budziły większe zaufanie niż w przypadku restauracji nieregionalnych.

Publikacja zostata sfinansowana ze środków przyznanych Wydziałowi Towaroznawstwa Uniwersytetu Ekonomicznego w Krakowie w ramach dotacji na utrzymanie potencjału badawczego.

\section{Literatura}

[1] Babicz-Zielińska E., Zabrocki R.: Polskie kuchnie regionalne ze szczególnym uwzględnieniem kuchni kaszubskiej. Żywność. Nauka. Technologia Jakość, 2003, 3 (36) Supl., 33-40.

[2] Bienia B., Sawicka B., Krochmal-Marczak B.: Żywność regionalna i tradycyjna w opinii mieszkańców powiatu krośnieńskiego. W: Żywność dla świadomego konsumenta. Red. K. Melski i D. Walkowiak-Tomczak. Wyd. UP w Poznaniu, Poznań 2016, ss. 94-103. 
[3] Björk P., Kauppinen-Räisänen H.: Exploring the multi-dimensionality of travellers' culinarygastronomic experiences. Current Issues in Tourism, 2016, 19 (12), 1260-1280.

[4] Dominik P.: Znaczenie żywności tradycyjnej w kształtowaniu poziomu i jakości życia jej konsumentów. Prace Nauk. UE we Wrocławiu, Wrocław 2017, 483, 44-56.

[5] Duda-Seifert M., Drozdowska M., Rogowski M.: Produkty turystyki kulinarnej Wrocławia i Poznania - analiza porównawcza. Turystyka Kulturowa, 2016, 5, 101-114.

[6] Dziadkowiec J.M.: Rynek usług gastronomicznych skierowanych do osób podróżujących samochodami - stan obecny i perspektywy. Studia Ekonomiczne. Zesz. Nauk. UE w Katowicach, 2016, 255, $156-165$

[7] Dziadkowiec J.M.: Jakość posiłków serwowanych przez lokale gastronomiczne kierujące usługi do zmotoryzowanych podróżnych - badania konsumenckie. Nauki Inż. i Technol., 2017, 2 (25), 35-45.

[8] Dziadkowiec J.M.: Jakość usług gastronomicznych z punktu widzenia zmotoryzowanego turysty. Wyd. Akapit, Kraków 2018.

[9] Dziadkowiec J.M.: Wymagania osób podróżujących samochodami wobec wybranych usług gastronomicznych. Wyd. UEK, Kraków 2016.

[10] Fields K.: Demand for the gastronomy tourism product: Motivational factors. In: Tourism and Gastronomy. Ed. A.M. Hjalager and G. Richards. Routledge, London 2002, pp. 35-50.

[11] Ha J., Jang S.S.: Effects of service quality and food quality: The moderating role of atmospherics in an ethnic restaurant segment. Int. J. Hospit. Manag., 2010, 29 (3), 520-529.

[12] Iwanicka A.: Postrzeganie wybranych elementów marketingowej jakości produktów regionalnych i tradycyjnych. Studia i Prace Naukowe Wydziału Nauk Ekonomicznych i Zarządzania Uniwersytetu Szczecińskiego, 2015, 39 (2), 447-458.

[13] Kim G., Eves A., Scarles C.: Building a model of local food consumption on trips and holidays: A grounded theory approach. Int. J. Hospit. Manag., 2009, 28 (3), 423-431.

[14] Kosicka-Gębska M., Tul-Krzyszczuk A., Gębski J.: Handel detaliczny żywnością w Polsce. Wyd. SGGW w Warszawie, Warszawa 2015.

[15] Kruczek Z., Krauzowicz M.: Turystyka kulinarna na Podhalu. Zesz. Nauk. Turystyka i Rekreacja, 2016, 2 (18), 17-33.

[16] Kuźniar W., Kawa M.: Konsumenci wobec regionalnych produktów tradycyjnych w kontekście ogólnoświatowych zmian w zachowaniach konsumentów na rynku żywności. Zesz. Nauk. SGGW w Warszawie - Problemy Rolnictwa Światowego, 2018, 18 (4), 304-312.

[17] Kwon D.Y.: What is ethnic food? J. Ethnic Foods, 2015, 2 (1), 1.

[18] Lista produktów tradycyjnych. [on-line]. Ministerstwa Rolnictwa i Rozwoju Wsi. Dostęp w Internecie [10.10.2018]: https://www.gov.pl/web/rolnictwo/lista-produktow-tradycyjnych12

[19] Mair H., Sumner J.: Leisure and Food. Routledge, New York City 2015.

[20] Makała H.: Tradycje w kuchni polskiej jako atrakcja dla turystów. Zesz. Nauk. Turystyka i Rekreacja, 2015, 1(15), 7-27.

[21] Mitura T.: Dziedzictwo kulinarne i jego wpływ na tworzenie markowego produktu turystycznego na przykładzie Szlaku Kulinarnego Podkarpackie Smaki. W: Region turystyczny - zarządzanie i rozwój. Narzędzia, metody, szanse i perspektywy. Red. M. Dębski i A. Jackiewicz. Wyd. Społecznej Akademii Nauk, Łódź-Warszawa 2017, ss. 205-218.

[22] Newerli-Guz J., Rybowska A.: Produkt tradycyjny i regionalny - luksus od święta czy na co dzień? Handel Wewnętrzny, 2015, 2 (355), 286-295.

[23] Nummedal M., Hall M.: Local food and tourism: An investigation of the New Zealand South Island's bed and breakfast section's use and perception of local food. Tourism Rev. Int., 2006, 9, 365378.

[24] Paluch A., Stoma M.: Analiza możliwości rozwoju produkcji oraz rynku produktów regionalnych i tradycyjnych w województwie lubelskim. Acta Sci. Pol., Technica Agraria, 2014, 13 (3-4), 37-47. 
[25] Regiony. [on line]. Culinary Heritage. Dostęp w Internecie [15.09.2018]: https://www.culinaryheritage.com/regions.asp

[26] Rozporządzenie Parlamentu Europejskiego i Rady (UE) nr 1151/2012 z dnia 21 listopada 2012 r. w sprawie systemów jakości produktów rolnych i środków spożywczych. Dz. U. L 343, s. 1-29, z 14.12.2012.

[27] Sala J.: Rynek żywnościowy jako element kształtujący atrakcyjność i tożsamość turystyczną Małopolski. Zesz. Nauk. Uniwersytetu Szczecińskiego, 2016, 3 (35), 209-222.

[28] Sieczko A.: Edukacyjny charakter polskich kuchni regionalnych. W: Turystyka wiejska a edukacja: różne poziomy, różne wymiary. Red. J. Sikora. Wyd. AR w Poznaniu, Poznań 2007, ss. 218-227.

[29] Sulek J.M., Hensley R.L.: The relative importance of food, atmosphere, and fairness of wait: The case of a full-service restaurant. Cornell Hotel and Restaurant Administration Quarterly, 2004, 45 (3), 235-247.

[30] Świstak E.: Zwiększenie konkurencyjności produktów regionalnych przez ich wykorzystanie w ofercie gastronomicznej. Rocz. Nauk. Stowarzyszenia Ekonomistów Rolnictwa i Agrobiznesu, 2014, XVI (3), 288-292.

[31] Tomczak J.: Szlak kulinarny jako przykład szlaku tematycznego. Prace i Studia Geograficzne, 2013, 52, 47-62.

[32] Cygan G: Tradycje związane z dziedzictwem kulinarnym Małopolski. [on line]. Małopolski Instytut Kultury. Dostęp w Internecie [15.09.2018]: http://szlakimalopolski.mik.krakow.pl/2014/08/25/ tradycje-zwiazane-z-dziedzictwem-kulinarnym-malopolski

[33] Tradycyjna kuchnia Małopolski: bajgle i flaczki po krakowsku. [on line]. Podróże.pl. Dostęp w Internecie [15.09.2018]: http://podroze.se.pl/polska/malopolskie/tradycyjna-kuchnia-malopolskiwplywy-autriackie-zy/1730

[34] Turystyka kulinarna w Polsce - trendy. Citybell Consulting, Warszawa 2013.

[35] Wang C.-Y., Mattila A.S.: The impact of servicescape cues on consumer prepurchase authenticity assessment and patronage intentions to ethnic restaurants. J. Hospit. Tourism Res., 2015, 39 (3), 346-372.

[36] Wilczyńska A.: Znajomość żywności gwarantowanej jakości i jej oznakowania wśród młodych konsumentów. Handel Wewnętrzny, 2015, 2 (355), 420-431.

[37] Żakowska-Biemans S., Kuc K.: Żywność tradycyjna i regionalna w opinii i zachowaniach polskich konsumentów. Żywność. Nauka. Technologia. Jakość, 2009, 3 (64), 105-114.

\section{CONSUMER EVALUATION OF QUALITY OF MEALS OFFERED BY RESTAURANTS OF REGIONAL NATURE}

\section{S u m m a ry}

Culinary traditions belong to the cultural heritage of a given region or country. The preservation of those traditions is not confined to households. A consumer, in particular a tourist, expects that regional and/or traditional products and dishes are the specialty of a restaurant of regional nature. This type of food is popularised during multiple trade fairs or taste festivals held in various regions of Poland, and this further increases the demand for those food products.

The objective of the survey study was to evaluate one of the aspects of the quality of catering services, i.e. the quality of meals that included: sensory values, health quality and availability. The object of the survey study covered restaurants of regional nature, where traditional and regional dishes should be offered. The survey conducted showed that where the respondents had an option to choose between regional and non-regional restaurants, they more likely chose the first one. However, they rather intuitively treated 
the term 'regional and traditional food' and, as a rule, they did not care whether or not the products offered were certified. The quality of meals offered at the regional venues was rated at a level of 3.41 (on a 5-point scale). This rate did not significantly deviate from the ratings for the other restaurants offering their services in the area analysed. In the case of regional restaurants, the sensory values of the meals served were rated the highest (3.81), whereas, in terms of their availability, the quality of those meals was rated a little lower (3.44) and, in terms of health quality, it was rated the lowest (3.20).

Key words: catering services, food quality, service quality, regional products, consumer satisfaction 